\title{
Anti-inflammatory effects of inhaled beclomethasone dipropionate in nonatopic asthmatics
}

\author{
M. Hoshino, Y. Nakamura
}

Anti-inflammatory effects of inhaled beclomethasone dipropionate in nonatopic asthmatics. M. Hoshino, Y. Nakamura. CERS Journals Ltd 1996.

ABSTRACT: The effects of inhaled beclomethasone dipropionate (BDP) on asthma symptoms and infiltration of the bronchial mucosa by inflammatory cells were investigated in an open study of $\mathbf{1 0}$ patients with mild-to-moderate nonatopic bronchial asthma.

Asthma scores were recorded in an asthma diary. Peak expiratory flow (PEF), PEF diurnal variation (PEF\%), forced expiratory volume in one second (FEV1\%), methacholine airway hypersensitivity (minimum dose of methacholine) (Dmin) were measured. Biopsy of the bronchial mucosa was performed before and after 8 weeks of treatment with BDP $\left(400 \mu \mathrm{g} \cdot \mathrm{day}^{-1}\right)$. The following inflammatory cells were immunostained: eosinophils with anti-EG2; mast cells with AA1; neutrophils with NP57; T-lymphocytes with anti-CD3, CD4, and CD8; and activated T-lymphocytes with anti-CD25.

There was a significant improvement in the asthma symptom score, PEF\%, FEV1\%, and Dmin after BDP therapy and the number of EG2-, AA1-, CD3-, CD4-, and CD25-positive cells decreased significantly.

We conclude that inhaled beclomethasone dipropionate inhibited inflammatory cell infiltration of airway tissue and that associated with this there was an improvement of symptoms in this open study of inhaled beclomethasone dipropionate in a group of nonatopic asthmatic subjects.

Eur Respir J., 1996, 9, 696-702.
Second Dept of Internal Medicine, Toho University School of Medicine, Tokyo, Japan.

Correspondence: M. Hoshino

Toho University School of Medicine

Second Dept of Internal Medicine

6-11-1 Oomori-nishi Ota-ku

Tokyo 143

Japan

Keywords: Airway inflammation beclomethasone dipropionate monoclonal antibody nonatopic asthma

Received: December 291994 Accepted after revision December 101995
Bronchial asthma is perceived as a chronic bronchial inflammatory disease associated with infiltration of eosinophils, mast cells and T-cells into the airway wall. This is demonstrated by biopsy of the bronchial mucosa [1, $2]$, and by examination of bronchoalveolar lavage (BAL) fluid [3], regardless of severity [4, 5].

Asthma can be divided. according to its nature, into two types: atopic (extrinsic) and nonatopic (intrinsic). The former is characterized by a type I allergic reaction, thought to result from the reaction of specific immunoglobulin $\mathrm{E}(\mathrm{IgE})$ antibody on mast cell or basophil with antigen, and where atopic symptoms are the result of congenital factors. In the latter, the antigen, if any, remains unidentified and the pathogenic factor is still unknown, although viral infection [6], receptor anomaly [7] and autoantibody [8] have been considered to be possible responsible factors. Type III and/or IV allergic reactions are also thought to play a causative role in the manifestation of bronchial asthma [9]. Nonatopic asthma is apt to occur in middle-aged and older individuals and often becomes intractable in these patients.

The infiltration of inflammatory cells into airway tissues is noted regardless of the type of asthma, although it is more severe in nonatopic asthma [10]. Therefore, the treatment of asthma is often aimed at the alleviation of chronic airway inflammation due to such cellular infiltration: for this purpose, combinations of bronchodilators such as $\beta_{2}$-agonist [11] and xanthine [12], but also anti-inflammatory agents, are variously used.
Use of corticosteroids was reported by WALSH and GRANT [13] to be highly effective for the treatment of asthma. Beclomethasone dipropionate (BDP), developed as a steroid for inhalation, was reported to be a useful treatment for asthma and exhibited minimal side-effects [14]. For long-term treatment, steroid inhalation is effective and safe in asthma if it is used at low dosage [15], or at high dosage for short-term treatment [16, 17]. Histopathologically in atopic asthma, steroid inhalation has been reported to increase the number of ciliated cells [18], suppress the infiltration of inflammatory cells [19, 20], and improve airway epithelial damage [21].

The present open study was designed to evaluate the effects of BDP inhalation both clinically and histopathologically in patients with mild-to-moderate nonatopic asthma, as this has not been previously studied. We find that BDP inhibits inflammatory cell infiltration of tissues in association with improvement both of clinical symptoms and lung function.

\section{Patients and methods}

\section{Patients}

The study included a total of 10 patients with mildto-moderate nonatopic asthma (three females and seven males, aged 47 yrs on average). Asthmatic patients were defined as: 1) those who had intermittent chest 
tightness, wheeze, cough, shortness of breath; 2) those who had reversible airway obstruction (variation in forced expiratory volume in one second (FEV1) or peak expiratory flow (PEF) of $20 \%$ or more); and 3) those who had increased airway hypersensitivity. The severity of asthma was graded as: mild, where the patient complained of mild intermittent dyspnoea which occurred once or twice a week; moderate, where the patients had dyspnoea occurring three times or more a week and an nocturnal attack of asthma occurring twice or more a month; and severe, where continuous exacerbation of dyspnoea and frequent nocturnal attacks were noted in spite of treatment.

Five of the asthmatics took intermittent inhaled $\beta_{2^{-}}$ agonist alone, five took oral theophylline and $\beta_{2}$-agonist in addition to inhaled $\beta_{2}$-agonist. None received oral or inhaled corticosteroids or cromolyn.

The patients were characterized by negative skin-prick tests to common allergens, as well as IgE radioallergosorbent (RAST) using various antigens, such as house dust mite, grass pollens, cat fur, dog hair and fungi. Their total serum IgE values were all within normal range. Additional antigen inhalation tests were carried out with 11 antigens to ensure their nonatopic status. Antigen extracts for skin-prick test were diluted in normal saline to prepare a 10 fold series of dilutions $\left(10^{-3}, 10^{-2}\right.$ and $\left.10^{-1}\right)$. However, the highest fungal concentration for inhalation was $10^{-2}$. The antigen dilutions were inhaled by a DeVilbiss 646 Nebulizer (DeVilbiss Co., Somerset, PA, USA) at a constant airflow of $5 \mathrm{~L} \cdot \mathrm{min}^{-1}$. FEV1 was measured after $10 \mathrm{~min}$ following a 2 min administration of saline. The FEV1 obtained was recorded as the baseline FEV1 value. For each of the antigens, FEV1 was measured in the same way as the baseline FEV1 in ascending order of concentration. The measurement was repeated to confirm whether the parameter would decrease by $20 \%$ or more from the baseline value. The parameter was measured 20, 30, 60 and $120 \mathrm{~min}$ after inhalation at the highest concentration of each antigen. Reduction in FEV1 did not exceed $20 \%$ in any of the patients (table 1)

Informed consent was obtained prior to the study, which was performed under the control of the Ethics Committee of our Institute. Permission was not given for a placebocontrolled arm to this study, which was therefore "open" in design. Patients acted as their own control and were biopsied both before and after treatment with the corticosteroid.

\section{Study design}

Following a 2 week observation period, the patients underwent bronchoscopy and were, subsequently, treated with BDP at $400 \mu \mathrm{g} \cdot \mathrm{day}^{-1}$ for 8 weeks. BDP inhalation was delivered from a pressurized metered-dose inhaler through a $750 \mathrm{~mL}$ volumatic spacer device (Glaxo Co., Tokyo, Japan). Patients were each directed to make a daily record of their use of BDP inhalation, $\beta_{2}$-agonist inhalation, theophylline and oral $\beta_{2}$-agonist in their patient diary. During the observation and treatment periods the patients recorded the severity of attack and cough, expectoration of sputum, disturbance in daily activities and sleep due to asthma, and the consumption of the given drug in their patient diary.

PEF was measured with an "Assess Peak Flow Meter" (HealthScan, Cedar Grove, NJ, USA) three times every morning and evening. The highest value was recorded. The diurnal variation in PEF was expressed as a ratio (\%) of the difference between PEFmax and PEFmin to PEFmax.

Bronchoscopic examination was performed twice: 1) at the end of the observation period; and 2) at the end of the 8 week period of BDP treatment. One week before the bronchoscopic examination (or at 1 week into observation and 7 weeks into treatment), airway hypersensitivity and lung function were measured and, for the patients who used theophylline, the serum level of theophylline was determined.

\section{Scoring of symptoms}

Six symptom scores were recorded daily on the diary card: 1) wheeze during the day using a graded scale as none $=0$, mild $=3$, moderate $=6$, severe $=9 ; 2$ ) amount of

Table 1. - Patient details

\begin{tabular}{|c|c|c|c|c|c|c|c|c|c|}
\hline $\begin{array}{l}\mathrm{Pt} \\
\text { No. }\end{array}$ & Sex & $\begin{array}{l}\text { Age } \\
\text { yrs }\end{array}$ & $\begin{array}{l}\text { FEV1 } \\
\% \text { pred }\end{array}$ & $\begin{array}{l}\text { Dmin } \\
\text { Unit }\end{array}$ & $\begin{array}{c}\operatorname{IgE} \\
\mathrm{IU} \cdot \mathrm{mL}^{-1}\end{array}$ & $\begin{array}{l}\text { IgE RAST } \\
\text { score }\end{array}$ & SPT & AIT & $\begin{array}{c}\text { Mean symptom } \\
\text { score before BDP }\end{array}$ \\
\hline 1 & M & 58 & 76 & 2.03 & 71 & 0 & -ve & -ve & 6.4 \\
\hline 2 & M & 50 & 65 & 0.73 & 67 & 0 & -ve & -ve & 7.5 \\
\hline 3 & $\mathrm{~F}$ & 30 & 72 & 1.41 & 31 & 0 & -ve & -ve & 3.2 \\
\hline 4 & $\mathrm{~F}$ & 58 & 70 & 0.39 & 89 & 0 & -ve & -ve & 9.4 \\
\hline 5 & M & 42 & 70 & 0.63 & 79 & 0 & -ve & -ve & 1.1 \\
\hline 6 & M & 48 & 75 & 0.29 & 66 & 0 & -ve & -ve & 1.3 \\
\hline 7 & $\mathrm{~F}$ & 42 & 60 & 0.35 & 60 & 0 & -ve & -ve & 12.8 \\
\hline 8 & M & 51 & 59 & 0.21 & 49 & 0 & - ve & -ve & 1.8 \\
\hline 9 & M & 55 & 76 & 1.40 & 15 & 0 & -ve & - ve & 5.6 \\
\hline 10 & M & 41 & 72 & 0.70 & 40 & 0 & -ve & -ve & 4.5 \\
\hline \multicolumn{3}{|c|}{ Mean \pm SEM } & $70 \pm 6$ & $0.81 \pm 0.58$ & $65.2 \pm 19.9$ & 0 & & & $5.4 \pm 3.8$ \\
\hline
\end{tabular}

Pt: patient; M: male; F: female; FEV1: forced expiratory volume in one second; Dmin: minimum dose of methacholine as the indicator for bronchial sensitivity; IgE: immunoglobulin E; RAST: radioallergosorbent test; SPT: skin-prick test; AIT: allergen inhalation test; -ve: negative; BDP: beclomethasone dipropionate; IU: immunizing unit; Unit: equal to $1 \mathrm{~min}$ of a $1.0 \mathrm{mg} \cdot \mathrm{mL}-1$ aerosol inhalation of methacholine. 
sputum was as graded small $=1$ or large $=2 ; 3$ ) expectoration of sputum as $\operatorname{good}=0$ or $b a d=1 ; 4)$ limitation of daily activity as none $=0$, mild $=6$, moderate $=12$, severe $=$ 18 ; and 5) nocturnal wheeze or nocturnal cough as none $=0$, mild $=3$, moderate $=6$, severe $=9$. The results were expressed as the daily mean of the sums of the six scores. The mean initial symptom score was calculated from the scores recorded for the 2 week observation period. In the same way, the mean posttreatment symptom score was calculated from those which were recorded for the 2 weeks during weeks $7-8$ of treatment.

\section{Functional assessment}

Airway hypersensitivity. The use of any bronchodilator was discontinued for 12 or more hours before the examination of methacholine-induced airway hypersensitivity. The examination was performed by the method of TAKISHIMA et al. [22] using an Astograph (Chest Co., Tokyo, Japan) direct-writing recorder, measuring doseresponse curves of respiratory resistance $(R \mathrm{rs})$, during continuous inhalation of methacholine at stepwise incremental concentration. Methacholine hydrochloride in isotonic saline was gradually increased to $49,98,195,390$, $781,1,563,3,125,6,250,12,500$ and $25,000 \mu \mathrm{g} \cdot \mathrm{mL}^{-1}$. At first, saline solution was inhaled and after $1 \mathrm{~min}$ was followed by successive inhalations of increased methacholine concentration. The minimum dose of methacholine (Dmin) was used as the indicator of bronchial sensitivity, i.e. the amount of the cumulative dose at the inflection point where the reciprocal of the $R$ rs decreased linearly. Dmin was scaled by a unit equal to one min of a $1.0 \mathrm{mg} \cdot \mathrm{mL}^{-1}$ aerosol inhalation of methacholine.

Biopsy of bronchial mucosa. Biopsy specimens were obtained during a bronchoscopy performed according to published guidelines [23]. The patients were premedicated with atropine sulphate $(0.6 \mathrm{mg}$ i.m. $)$ and diazepam (5 mg i.v.) for sedation, and then received two puffs $(200 \mu \mathrm{g})$ of salbutamol. Four percent lidocaine was sprayed for local anaesthesia of the pharynx and the larynx. The bronchoscope (BF-20, Olympus Co., Tokyo, Japan) was inserted via the mouth following surface anaesthesia of the trachea and the bronchi with $2 \%$ lidocaine. Oxygen was administered via a nasal cannula at $4 \mathrm{~L} \cdot \mathrm{min}^{-1}$ and arterial oxygen saturation was monitored with a finger oximeter (Biox 3740, Pulse Oximeter, Ohmeda, Louiville, KY, USA). Using alligator forceps (FB-15C, Olympus), bronchial biopsy was performed at: 1) the right main bronchus upper lobe bronchus bifurcation, 2) the bifurcation of the right middle lobe; and 3 ) the right B6 inlet. During the second biopsy, tissue samples were obtained from the equivalent sites in the contralateral lung.

Histopathological examination. The tissue specimens were covered in ornithine carbamyl transferase (OCT) compound, rapidly frozen in dry ice-acetone and stored in a deep freeze at $-70^{\circ} \mathrm{C}$. Specimens from all the tissues were prepared by staining with haematoxylin and eosin (H\&E). Cryostat slices $4 \mu \mathrm{m}$ thick were placed on albumin-coated slides, allowed to air dry for $60 \mathrm{~min}$, and then fixed for $15 \mathrm{~min}$ in cold acetone $\left(-20^{\circ} \mathrm{C}\right)$.
According to the method of NAKAne and Pierce [24], the prepared tissue slices were washed for $5 \mathrm{~min}$ in phosphate buffered saline (PBS) five times and then treated with $10 \%$ normal porcine serum at room temperature for $30 \mathrm{~min}$. After these procedures, the preparations were reacted with monoclonal antibodies as the primary antibody. To detect activated eosinophils, tissue sections were immunostained with anti-EG2 (Nichirei, Tokyo, Japan), mast cells with AA1 (Dako Ltd, High Wycombe, UK), neutrophils with NP57 (Dako Ltd), T-lymphocytes with CD3 (Becton-Dickinson, Cowley, UK), CD4 (BectonDickinson) and CD8 (Becton-Dickinson), and activated T-lymphocytes were identified using anti-CD25 (Dako Ltd). All these antibodies were diluted to 1:50, except for NP57 (1:100). Staining reactions were performed at $37^{\circ} \mathrm{C}$ for $1 \mathrm{~h}$. After washing in PBS, sections were reacted with peroxidase-labelled mouse anti-immunoglobulin $\mathrm{G}(\mathrm{IgG})\left(5 \mathrm{mg} \cdot \mathrm{mL}^{-1}\right)$ as a secondary antibody at room temperature for $1 \mathrm{~h}$, and washed again with PBS, which contained $\mathrm{NaN}_{3}\left(65 \mathrm{mg} \cdot \mathrm{dL}^{-1}\right)$ in order to avoid nonspecific reaction caused by the endogenous peroxidase of eosinophils and neutrophils.

Colour development was performed for $5 \mathrm{~min}$ with 3,3'-diaminobenzidine.4 HCl. Methylene green was used for nuclear staining, rinsed in running water, dehydrated with alcohol, and cleared with xylol. For negative controls, tissues were prepared omitting the primary antibodies and using mouse $\operatorname{IgG} 2 \mathrm{a}$ myeloma protein as a substitute for the primary antisera. All tissue samples were stained within $24 \mathrm{~h}$ after collection.

The specimens were all coded to blind the observer to treatment and sampling times: each section was observed by optical microscopy at $\times 400$ magnification $(\mathrm{BH} 2$, Olympus). The same blinded observer counted the number of cells in five different fields and calculated the number of cells per field. The stained cells were counted only in intact mucosa, excluding epithelium, glands, blood vessels and muscle. The contour of the tissue in which cells were counted was traced with computer software (NEC Co., Tokyo, Japan) on a video display (ITC-370, Olympus) and the area was calculated to determine the number of cells per unit area $\left(\mathrm{mm}^{-2}\right)$ tissue.

\section{Statistical analyses}

The Shapiro-Wilk test was used, whether data distribution was normal or not [25]. Two-tailed Wilcoxon's signed-rank test was used to assess differences in paired data for the mean symptom scores, PEFmax, and diurnal variation in PEF. Two-tailed paired Student's t-test was used for FEV1\%, Dmin, and serum levels of theophylline. Wilcoxon's signed-rank test was used for statistical comparison between the number of cells per unit area before and after BDP inhalation. All data are expressed as mean \pm SEM. Differences at $p$-value less than 0.05 were considered to be statistically significant.

\section{Results}

There was no problem with regard to the safety of the bronchoscopic procedure in our series of patients. After 
the first bronchoscopic study, two patients complained of mild dyspnoea: an additional $\beta_{2}$-agonist inhalation was administered and $10 \mathrm{mg}$ oral prednisone was added for 2 days.

\section{Clinical and functional examination}

Symptom scores decreased significantly $(\mathrm{p}<0.05)$ after 8 weeks of BDP treatment, from an initial score of $5.4 \pm 3.8$ to $2.3 \pm 2.0$ as recorded during the observation period. The percentage of diurnal variation in PEF decreased significantly $(\mathrm{p}<0.05)$ from $24 \pm 4$ to $13 \pm 4 \%$. PEF increased from $413 \pm 97 \mathrm{~L} \cdot \mathrm{min}^{-1}$ in the observation period to $478 \pm 72 \mathrm{~L} \cdot \mathrm{min}^{-1}$ after treatment. FEV1\% increased significantly $(\mathrm{p}<0.05)$ from $70 \pm 6 \%$ to $74 \pm 5 \%$, and Dmin from $0.81 \pm 0.58$ to $1.56 \pm 0.86$ units. The serum level of theophylline did not change significantly, being $4.6 \pm 2.1$ $\mu \mathrm{g} \cdot \mathrm{mL}^{-1}$ in the observation period and $4.0 \pm 1.7 \mu \mathrm{g} \cdot \mathrm{mL}^{-1}$ after treatment (fig. 1).

\section{Histopathological observation}

For the counting of stained cells, the specimen showing the least damage at biopsy was selected from the tissue samples taken from the three different anatomical sites. Figure 2 shows representative findings on EG2and CD4-stained specimens.

After treatment with BDP at $400 \mu \mathrm{g} \cdot \mathrm{day}^{-1}$ for 8 weeks, the number of EG2-positive cells decreased significantly from an initial average of $45.3 \pm 16.4$ to $15.4 \pm 7.1$
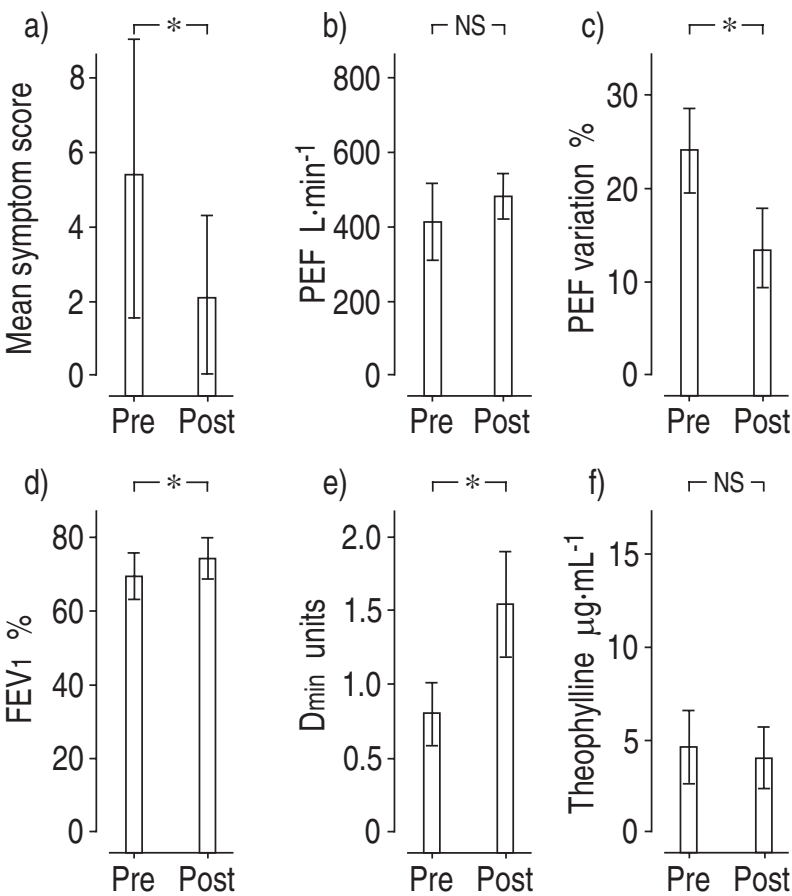

Fig 1 - - a) mean daily symptom scores; b) best peak expiratory flow (PEF); c) diurnal PEF variation, before (Pre) and after (Post) 8 weeks treatment with BDP. Measurements of: d) FEV1\%; e) Dmin methacholine; and f) serum theophylline value, were performed 7 days before treatment and before the second bronchoscopy ( 7 weeks of treatment). Data are expressed as mean \pm SEM. *: $\mathrm{p}<0.05$. BDP: beclomethasone dipropionate; FEV1: forced expiratory volume in one second; Dmin: minimum dose of methacholine as indicator for bronchial sensitivity; NS: nonsignificant. a)

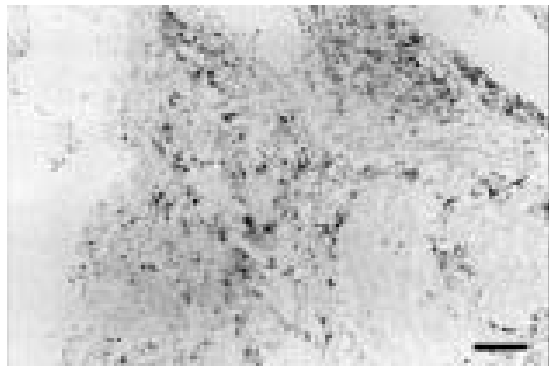

b)

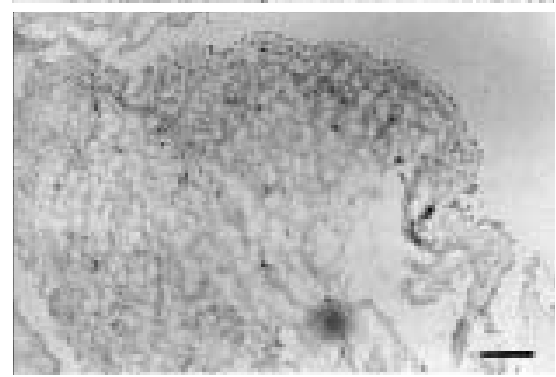

c)

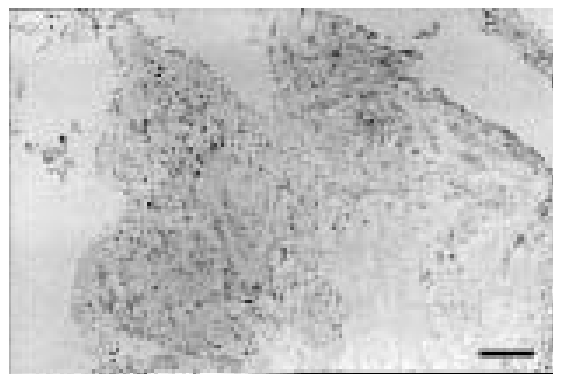

d)

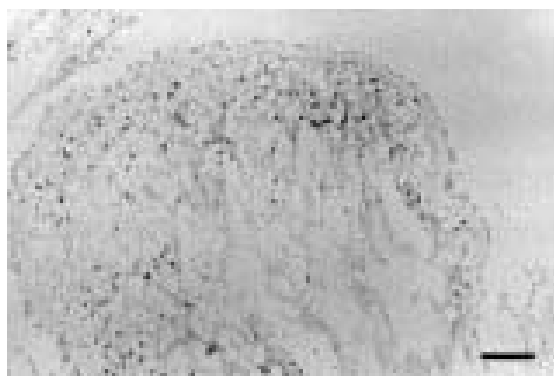

Fig. 2. - Bronchial mucosa from an asthmatic patient. Two sections demonstrating EG2-positive cells: a) before and b) after BDP treatment; and CD4-positive cells; c) before and d) after BDP treatment. BDP: beclomethasone dipropionate. (Original magnification for all four panels is $\times 150$; internal scale bar $=0.1 \mathrm{~mm}$ ).

cells $\cdot \mathrm{mm}^{-2}$, AA1-positive mast cells decreased from $24.0 \pm 2.6$ to $18.6 \pm 3.0$ cells $\cdot \mathrm{mm}^{-2}, \mathrm{CD} 3$-positive T-cells from $180.6 \pm 41.9$ to $92.3 \pm 18.6$ cells $\cdot \mathrm{mm}^{-2}, \mathrm{CD} 4$-positive T-cells from $90.1 \pm 22.3$ to $44.3 \pm 11.9$ cells $\cdot \mathrm{mm}^{-2}$ and CD25positive T-cells from $10.4 \pm 5.1$ to $3.9 \pm 2.3$ cells $\cdot \mathrm{mm}^{-2}$ (all $\mathrm{p}<0.05)$. However, the number of NP57-positive neutrophils and CD8-positive T-cells did not change significantly (figs. 3 and 4).

\section{Discussion}

The present study was uncontrolled due to the constraint of the Ethics Committee of our Institute, which felt that the use of a placebo arm instead of an effective inhaled steroid was inappropriate in a symptomatic patient population. Subjects with severe asthma were not included for the same reason. Consequently, we cannot 


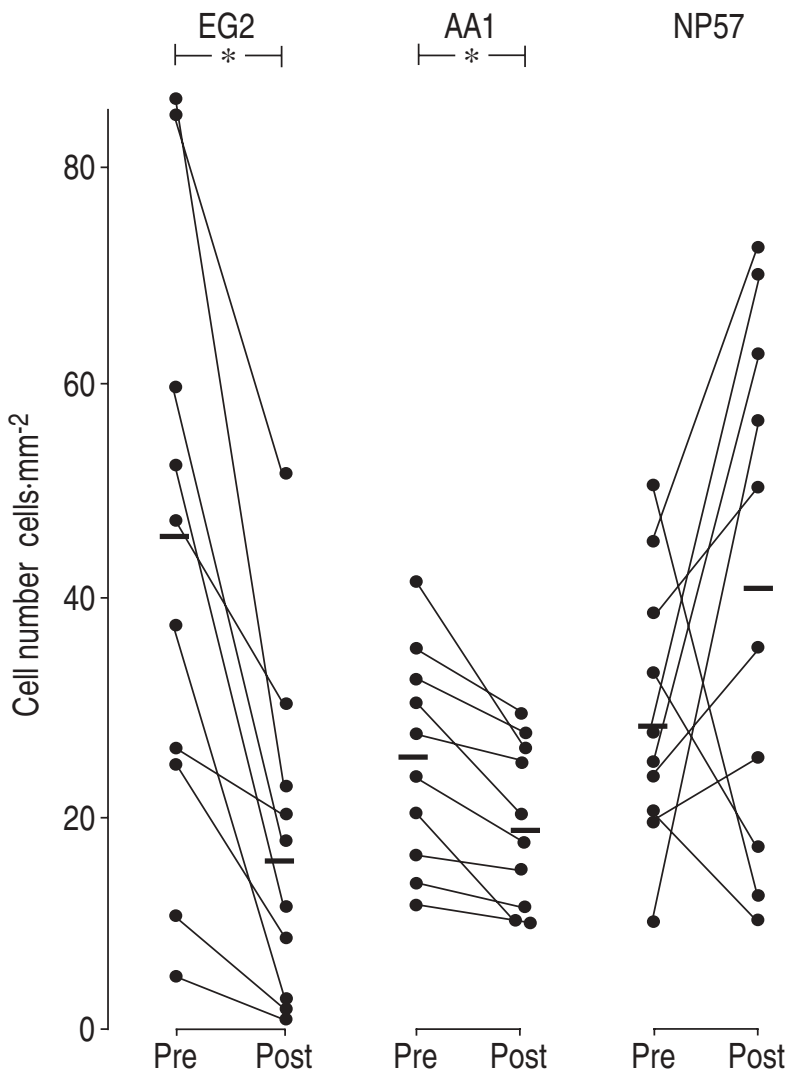

Fig. 3. - Numbers of EG2-positive cells (eosinophils), AA1-positive cells (mast cells) and NP57-positive cells (neutrophils) per square millimetre mucosa in individual cases. Mean values are represented by the horizontal bars. Pre: pretreatment; Post: posttreatment with beclomethasone dipropionate (BDP). * : $\mathrm{p}<0.05$.
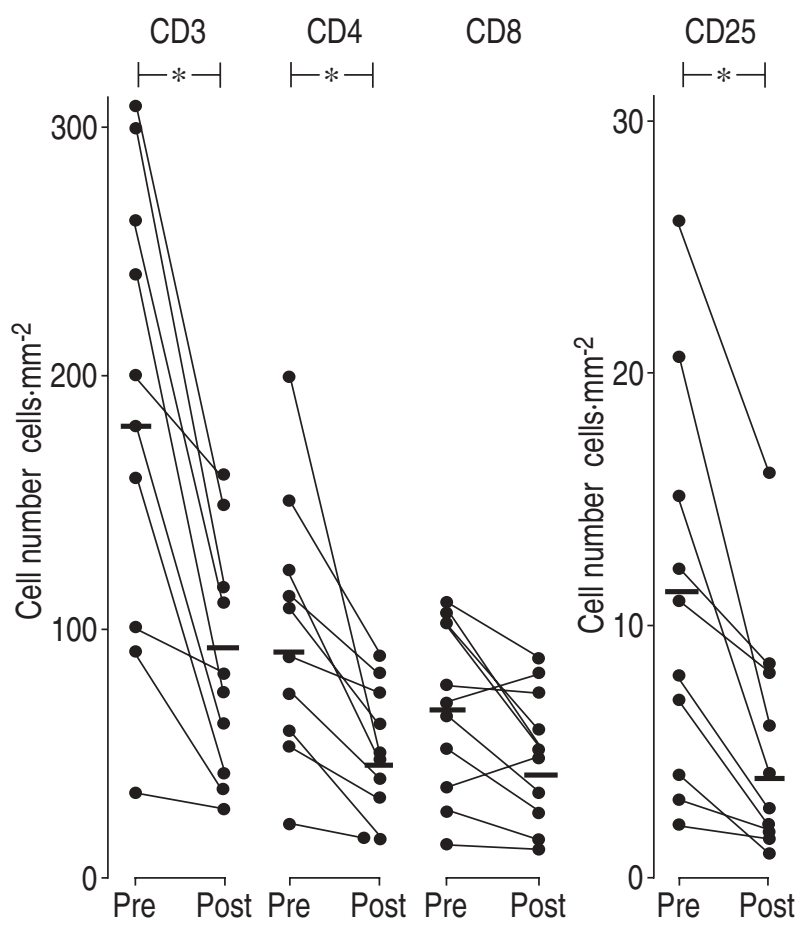

Fig. 4. - Numbers of T-lymphocyte (CD3, CD4, CD8) and activated T-lymphocyte (CD25) count per square millimetre mucosa in individual cases. Mean values are represented by the horizontal bars. Pre: pretreatment; Post: posttreatment with beclomethasone dipropionate (BDP). *: $\mathrm{p}<0.05$ be certain that the improvement in asthma was totally as result of BDP inhalation. However, the clinical and histopathological results correspond to those of other studies in allergic asthma $[19,20]$, and indicate that BDP inhalation seemed to suppress cellular infiltration in airway tissues and also improve airway hypersensitivity in nonatopic asthma.

Four hundred micrograms of inhaled BDP is known to have antiasthma effects comparable to $5-7.5 \mathrm{mg}$ of oral prednisone [26]. SVENDSEN et al. [27] reported that FEV1, PEF, forced vital capacity (FVC) and airway hypersensitivity improved significantly after 8 weeks of treatment of atopic asthma with BDP inhalation at 400 $\mu \mathrm{g} \cdot$ day $^{-1}$. In addition, we found improvements in symptom score, $\mathrm{PEF} \%$, FEV1, and Dmin in nonatopic asthma after the same dose of BDP.

LUNDGREN et al. [21] also demonstrated symptomatic improvement in nonatopic asthma; however, they observed the total number of inflammatory cells and not their subtypes. EG2 immunopositive eosinophils are thought to represent activated eosinophils [28]: an increase in their number is thought to lead to the release of tissuedamaging granular proteins, which damage the airway epithelium and results in airway hypersensitivity [2931]. The fact that the number of EG2-positive eosinophils in the bronchial mucosa reported here significantly decreased after treatment, is consistent with the report that steroid inhalation decreases eosinophil cationic protein (ECP) levels in BAL [32], and reports [19, 20] that the number of eosinophils in bronchial mucosa decreases after treatment with inhaled steroid. Regarding the mechanism of action of steroids on eosinophils, there have been suggestions that steroids act directly on eosinophils to suppress their infiltration in airway tissues [33], that interleukin (IL)-5 plays an important role in the chemotaxis of eosinophils in airway tissues [34], and that steroids suppress gene expression by IL-5 [35].

AA1 antibody, which does not stain basophils in peripheral blood, seems to be specific for mast cells [36]. Several studies have demonstrated that there is no difference between asthmatic subjects and normal subjects with regard to the number of mast cells in the airway wall [37, 38]. However, there have been other reports that asthmatic patients have a greater number of mast cells in bronchial mucosal epithelium than normal subjects $[39,40]$. A recent report suggested that stem cell factor (SCF) is a differentiation factor of human mast cells [41]. If so, the decrease in the number of mast cells after BDP inhalation may be as a result of the suppression of mast cell differentiation by BDP.

In a biopsy study on bronchial mucosa in atopic asthma and nonatopic asthma, the numbers of CD3-, CD4and CD25-positive T-cells were found to be significantly increased in patients with nonatopic asthma, compared to normal subjects, but there was no significant difference in the number of CD8-positive cells, and, in atopic asthma, only CD25-positive cells increased in number [10]. CD25-positivity is considered to be a marker of activated T-cells, although it may also be expressed on macrophages. WALKER et al. [42] reported that T-cell activation and the cytokine pattern in BAL differed between atopic asthma and nonatopic asthma. Unlike CD3-, CD4- and CD25-positive T-cells, which decreased significantly in number after treatment with BDP 
inhalation, CD8-positive cells did not. A possible reason is that steroids may decrease the number of lymphocytes - mainly T-cells [43], especially CD4-positive cells [44, 45], in peripheral blood. RoBinson et al. [46] reported that the number of cells expressing messenger ribonucleic acid (mRNA) for IL-4 and IL-5 in BAL from asthmatic patients decreased significantly after steroid therapy. The reduction in the number of T-cells after treatment with BDP inhalation in our study may be a result of the inhibition of cytokine production by BDP.

The suggestion that the number of neutrophils increases in airway tissues of asthmatic patients has not been confirmed in BAL [3, 47], or biopsy of the bronchial mucosa [5, 38]. This does not suggest that neutrophils play an important role in chronic asthma, although they take part in the immediate reaction to allergen. Usually, the number of neutrophils increases after the administration of steroids [48]. However, in our study, the number of NP57-positive neutrophils did not significantly increase after BDP.

Theophylline has been known to have an anti-inflammatory action $[49,50]$. However, in our study, the serum level of theophylline was almost unchanged before and after BDP. Consequently, it is possible to ignore its effect on asthmatic symptoms or improvement of inflammation which, we believe, is directly due to BDP.

In conclusion, we have demonstrated that the treatment of nonatopic asthmatics with BDP inhalation at 400 $\mu \mathrm{g} \cdot \mathrm{day}^{-1}$ for 8 weeks results in a significant improvement in asthmatic symptoms, diurnal variation in PEF, FEV $1 \%$ and airway hypersensitivity. The present histopathological findings on bronchial mucosa demonstrate that the number of eosinophils, mast cells and CD3-, CD4- and CD25-positive T-cells decrease significantly after BDP treatment. In this regard, the inflammation both of atopic and nonatopic asthma is responsive to corticosteroid treatment given by the inhaled route.

\section{References}

1. Jeffery PK, Wardlaw AJ, Nelson FC, Collins JV, Kay AB. Bronchial biopsies in stable asthma: an ultrastructural, quantitative study and correlation with hyperreactivity. Am Rev Respir Dis 1989; 140: 1745-1753.

2. Djukanovî́c R, Wilson JW, Lai CKW, Holgate ST, Howarth PH. The safety aspects of fiberoptic bronchoscopy, bronchoalveolar lavage, and endobronchial biopsy in asthma. Am Rev Respir Dis 1991; 143: 772-777.

3. Beasley R, Roche WR, Roberts JA, Holgate ST. Cellular events in the bronchi in mild asthma and after bronchial provocation. Am Rev Respir Dis 1989; 139: 806-817.

4. Walker C, Kaegi MK, Braun P, Blaser K. Activated Tcells and eosinophilia in bronchoalveolar lavages from subjects with asthma correlated with disease severity. $J$ Allergy Clin Immunol 1991; 88: 935-942.

5. Azzawi M, Bradley B, Jeffery PK, et al. Identification of activated T-lymphocytes and eosinophils in bronchial biopsies in stable atopic asthma. Am Rev Respir Dis 1990; 142: 1407-1413.

6. Li JTC, O'Connell EJ. Viral infections and asthma. Ann Allergy 1987; 59: 321-328.

7. Sventivanyi A. The beta-adrenergic theory of the atopic abnormality in bronchial asthma. J Allergy 1968; 42: 203-232.
8. Turner-Warwick M. Autoantibodies in allergic respiratory diseases. Prog Immunol 1974; 11: 283-292.

9. Pepys J, Hutchcroft BJ. Bronchial provocation tests in etiologic diagnosis and analysis of asthma. Am Rev Respir Dis 1975; 112: 829-859.

10. Bentley AM, Menz G, Storz CHR, et al. Identification of T-lymphocytes, macrophages and activated eosinophils in the bronchial mucosa in intrinsic asthma: relationship to symptoms and bronchial responsiveness. Am Rev Respir Dis 1992; 146: 500-506.

11. Laitinen LA, Laitinen A, Haahtela T. A comparative study of the effects of an inhaled corticosteroid, budesonide, and a $\beta_{2}$-agonist, terbutaline, on airway inflammation in newly diagnosed asthma: a randomized, double-blind, parallel-group controlled trial. J Allergy Clin Immnol 1992; 90: 32-42.

12. Dutoit JI, Salome CM, Woolcock AJ. Inhaled corticosteroids reduce the severity of bronchial hyperresponsiveness in asthma but oral theophylline does not. Am Rev Respir Dis 1987; 136: 1174-1178.

13. Walsh SD, Grant IWB. Corticosteroids in treatment of chronic asthma. Br Med J 1966; 2: 796-802.

14. Morrow Brown H, Storey G, George WHS. Beclomethasone dipropionate: a new steroid aerosol for the treatment of allergic asthma. Br Med J 1972; 1: 585-590.

15. Kerrebijn KF, van Essen-Zandvliet EEM, Neijens HJ. Effect of long-term treatment with inhaled corticosteroid and beta-agonists on the bronchial responsiveness in children with asthma. J Allergy Clin Immunol 1987; 79: 653-659.

16. Juniper EF, Kline PA, Vanzieleghem MA, Ramsdale EH, O'Bryne PM, Hargreave FE. Effect of long-term treatment with an inhaled corticosteroid on airway hyperresponsiveness and clinical asthma in non-steroid-dependent asthmatics. Am Rev Respir Dis 1990; 142: 632-636.

17. Salmeron S, Guerin JC, Godard P, Renon D, HenryAmar M, Duroux P, Taytard A. High doses of inhaled corticosteroids in unstable chronic asthma: a multicenter, double-blind, placebo-controlled study. Am Rev Respir Dis 1989; 140: 167-171.

18. Heino M, Karjalainen J, Ylikoski J, Laitinen A, Laitinen LA. Bronchial ciliogenesis and oral steroid treatment in patients with asthma. Br J Dis Chest 1988; 82: 175-178.

19. Jeffery PK, Godfrey RW, Ädelroth E, Nelson F, Rogers A, Johansson S-A. Effects of treatment on airway inflammation and thickening of basement membrane reticular collagen in asthma. Am Rev Respir Dis 1992; 145: 890-899.

20. Djukanović R, Wilson JW, Britten KM, et al. Effect of an inhaled corticosteroid on airway inflammation and symptoms in asthma. Am Rev Respir Dis 1992; 145: 669-674.

21. Lundgren R, Söderberg M, Hörstedt P, Stenling R. Morphological studies of bronchial mucosal biopsies from asthmatics before and after ten years of treatment with inhaled steroid. Eur Respir J 1988; 1: 883-889.

22. Takishima T, Hida W, Sasaki H, Suzuki S, Sasaki T. Directing-writing recorder of the dose-response curves of the airway to methacholine. Chest $1981 ; 80: 600$ 606.

23. Bleecke ER. Workshop summary and guidelines: investigative use of bronchoscopy, lavage and bronchial biopsies in asthma and other airways disease. Clin Exp Allergy 1991; 21: 533-539.

24. Nakane PK, Pierce GB. Enzyme-labelled antibodies: preparation and application for localization of antigens. J Histochem Cytochem 1966; 14: 929-931. 
25. Shapiro SS, Wilk MB. An analysis of variance test for normality. Biometrika 1965; 52: 591-612.

26. British Thoracic and Tuberculosis Association. A trial of inhaled corticosteroids in patients receiving prednisone. J Dis Chest 1976; 70: 95-103.

27. Svendsen UG, Frolund L, Madsen F, Nielsen NH, HolsteinRathlou NH, Weeke B. A comparison of the effects of sodium cromoglycate and beclomethasone dipropionate on pulmonary function and bronchial hyperreactivity in subjects with asthma. J Allergy Clin Immunol 1987; 80: 68-74.

28. Tai P-C, Spry CJF, Peterson C, Venge P, Olsson I. Monoclonal antibodies distinguish between storage and secreted forms of eosinophil cationic protein. Nature 1984; 309: 182-184.

29. Gleich GJ, Frigas E, Loegering DA, Wassom DL, Steinmuller D. Cytotoxic properties of the eosinophil major basic protein. J Immunol 1979; 123: 2925-2927.

30. Gundel RH, Letts LG, Gleich GJ. Human eosinophil major basic protein induces airway constriction and airway hyperresponsiveness in primates. J Clin Invest 1991; 87: $1470-1473$.

31. Motojima S, Frigas E, Loegering DA, Gleich GJ. Toxicity of eosinophil cationic proteins for guinea-pig tracheal epithelium in vivo. Am Rev Respir Dis 1989; 139: 801805

32. Ädelroth E, Rosenhall L, Johansson S-Å, Linden M, Venge P. Inflammatory cells and eosinophilic activity in asthmatics investigated by bronchoalveolar lavage: the effects of anti-asthmatic treatment with budesonide or terbutaline. Am Rev Respir Dis 1990; 142: 91-99.

33. Clark PAF, Gallin JI, Fauci AS. Effects of in vivo prednisone on in vitro eosinophil and neutrophil adherence and chemotaxis. Blood 1979; 53: 633-641.

34. Hamid Q, Azzawi M, Sun Ying, et al. Expression of mRNA for interleukin-5 in mucosal bronchial biopsies from asthma. J Clin Invest 1991; 87: 1541-1546.

35. Rolfe FG, Hughes JM, Armour CL, Sewell WA. Inhibition of interleukin-5 gene expression by dexamethasone. Immunology 1992; 77: 494-499.

36. Walls AF, Jones DB, Williams JH, Church MK, Holgate ST. Immunohistochemical identification of mast cells in formaldehyde-fixed tissue using monoclonal antibodies specific for tryptase. J Pathol 1990; 162: 119-126.

37. Djukanović R, Wilson JW, Britten KM, et al. Quantitation of mast cells and eosinophils in the bronchial mucosa of symptomatic atopic asthmatics and healthy control subjects using immonohistochemistry. Am Rev Respir Dis 1990; 142: 863-871.

38. Bradley BL, Azzawi M, Jacobson M, et al. Eosinophils, T-lymphocytes, mast cells, neutrophils and macrophages in bronchial biopsy specimens from atopic subjects with asthma: comparison with biopsy specimens from atopic subjects without asthma and normal control subjects and relationship to bronchial hyperresponsiveness. J Allergy Clin 1991; 88: 661-674.

39. Laitinen LA, Laitinen A, Haahtera T. Airway mucosal inflammation even in patients with newly diagnosed asthma. Am Rev Respir Dis 1993; 147: 697-704.

40. Pesci A, Foresi A, Bertorelli G, Chetta A, Oliveri D. Histochemical characteristics and degranulation of mast cells in epithelium and lamina propria of bronchial biopsies from asthmatic and normal subjects. Am Rev Respir Dis 1993; 147: 684-689.

41. Valent P, Spanblöchl E, Sperr WR, et al. Induction of differentiation of human mast cells from bone marrow and peripheral blood mononuclear cells by recombinant human stem cell factor/kit-ligand in long-term culture. Blood 1992; 80: 2237-2245.

42. Walker C, Bode E, Boer L, Hansel TT, Blaser K, Virchow JC Jr. Allergic and nonallergic asthmatics have distinct patterns of T-cell activation and cytokine production in peripheral blood and bronchoalveolar lavage. Am Rev Respir Dis 1992; 146: 109-115.

43. Yu DTY, Clements PJ, Paulus HE, Peter JB, Levy J, Barnett EV. Human lymphocyte subpopulations: effect of corticosteroids. J Clin Invest 1974; 53: 565-571.

44. Haynes BF, Fauci AS. The differential effect of in vivo hydrocortisone on the kinetics of subpopulations of human peripheral blood thymus-derived lymphocytes. J Clin Invest 1978; 61: 703-707.

45. Cupps TR, Edgar LC, Thomas CA, Fauci AS. Multiple mechanisms of B-cell immunoregulation in man after administration of in vivo corticosteroids. J Immunol 1984; 132: $170-175$.

46. Robinson D, Hamid Q, Sun Ying, et al. Prednisolone treatment in asthma is associated with modulation of bronchoalveolar lavage cell interleukin-4, interleukin-5, and interferon- $\gamma$ cytokine gene expression. Am Rev Respir Dis 1993; 148: 401-406.

47. Wardlaw AJ, Dunnette S, Gleich GJ, Collins JV, Kay AB. Eosinophils and mast cells in bronchoalveolar lavage in subjects with mild asthma: relationship to bronchial reactivity. Am Rev Respir Dis 1988; 137: 62-69.

48. Tanizaki Y, Kitani H, Okazaki M, et al. Changes in bronchoalveolar cell profiles of asthma patients induced by long-term glucocorticoid therapy. Jpn J Thorac Dis 1993; 31: 717-724.

49. Pauwels RA. New aspects of the therapeutic potential of theophylline in asthma. J Allergy Clin Immunol 1989; 83: 548-553.

50. Sullivan P, Bekir S, Jaffar Z, Page C, Jeffery P, Costello J. Anti-inflammatory effects of low-dose oral theophylline in atopic asthma. Lancet 1994; 343: 1006-1008. 